To The Editor

The Forestry Chronicle

Dear Sir:

Having read your publication with interest for some time, I have noted its progression to a very readable style. It is a pleasure to find your humorous gems tucked away in the most unlikely places. Such levity in a trade publication is as refreshing as it is unexpected.

Among my favourites has been the anonymous Nemorensus. ${ }^{1} \mathrm{I}$ had been wondering about his identity, suspecting the Editor of a hidden talent, but I respected the freedom provided by a pseudonym and have not actively sought to satisfy my curiosity.

Now, however, I know who it is! And I regret to say that I am shocked. I am also disappointed in one whose friendship I had value.

I frequently have flights of sylvan fancy, but I prefer to keep them to myself, enjoying a quiet chuckle now and then as I trudge wearily from class to class. It isn't an easy task, trying to enlighten starry-eyed forestry novitiates about the real world. But now I am exposed. My students and colleagues will laugh at me (behind my back of course) whenever a secret smile flits across my care-creased face.

The article on page 12, Vol. 49, No. 1, February, 1973 exposed me, but it also exposed Nemorensus, who possibly was unaware that I had not discussed with anyone else my latest theories on International Forestry Units - a solution to a mensurational nightmare. I consider this unwarranted theft of some original thinking, freely discussed with a trusted, former colleague, to be unethical and reprehensible. I may sue. Or at least file a complaint with the Practice and Ethics Committee.

My latest ideas were to have been revealed at the IASTSN meeting in Geneva in June, but now, of course, I shall have nothing new to report on that subject, since all IASTSN members are avid readers of The Forestry Chronicle. What hurts most is that the rapscallion hadn't the courtesy to let me know of his intention to use my work in the column he writes for you. If he had mentioned it I could have explained that I really was serious about this innovation.

It is no consolation that he had a small twinge of conscience and credited me with the original thinking. But why did he make a mockery of such a useful idea? Unfortunately, N. doesn't listen any better now than he did as a student. Fernows indeed. I spoke of infernoes, of course. But he missed altogether my suggestions about Pinchots of National Forest, Greeleys of grazing land, Roths of allowable cut, in the U.S. How could he have missed Orchards of seed, Fliegers of budworm-kill, Zavitz of reforestation and Irvings of pulp, or was it oil?

Alas there are too few of my suggestions left, and since the concept has been enunciated in an international journal I must now devote my free time to developing a new original theory for Geneva in June. It won't be easy.

On reflection and in conclusion, may I say that $\mathrm{I}$ am a patient and tolerant old man, so if $I$ receive an apology from Nemorensis I shall not reveal his identity for fear of destroying a bright young man who still has much to offer the profession. I trust that this one error in judgement and my admonition will redirect his future efforts to less flagrant abuse of confidences freely shared.

$$
\begin{aligned}
& \text { Sincerely yours, } \\
& \text { R. E. Cluse } \\
& \text { Ivy-on-Wall, Canada. }
\end{aligned}
$$

P.S. In future we could rate the quality of publications in Fayles, or would that leave the wrong impression?

\footnotetext{
'Editor's Note. The Professor appears to need new glasses. Whispers through the trees is written by Nemorensis. Perhaps, though, he was on one of his flights of fancy as he does use the correct spelling in the last paragraph of his letter. Or, regrettably, he may have suffered another misfortune of the type described by $\mathrm{N}$. in his column opposite.
} 


\section{Whispers through the trees}

I am sure that Professor R. E. Cluse will not mind if I tell of a misfortune that befell him last year and which has most likely been responsible for his feeling out of sorts more frequently than usual.

Professor Cluse has always held that one should not only practise what one preaches but also that it is befitting for a forester to show publicly a concern for trees and the use of wood. Long before the present fad to reduce automobile pollution Professor Cluse used a bicycle for transportation. Indeed, over the years, many of the roads and trails in our forests have been traversed by the good professor. The folk song "Le maudit cycliste de St. Christophe" owes its existence, in a sense, to a habit of his. In very hilly country he customarily bicycies at night and claims that in the darkness he does not see the grades as well and therefore does better on the uphills. Near midnight, while travelling in the Laurentides he overtook two 'bûche- rons' who were in a state such that they were frightened out of their wits by the apparition on two wheels. Subsequently, one of them composed the song as a record of the experience.

The professor's bicycle was of a vintage that had wooden rims; these he proudly pointed out as being lighter than metal and more shock resistant. Some time ago he received an invitation to visit the Faculty of Forestry at Vancouver and accordingly travelled out and stayed with a colleague who lived in a northerly section of that city which receives an inordinate amount of precipitation. The bicycle was left outside and the wooden rims succumbed to the mild wet conditions and became soft and rotten. Thus one morning, when the professor with customary vigour jumped on his bicycle and set off for the Grey Point Campus, a disaster occurred. As he proceeded down the street he was forced in towards the curb by a motorcyclist and his wooden front wheel stuck in the grating of a storm drain. Such stresses and strains were involved that the punky wood gave way and the poor professor hurtled through the air and struck a native westerner who stood rooted to the spot, by nameDouglas Fir. Needless to say the professor came off second best.

The upshot was that the bruised and battered professor with a very sore head was not only confined to his bed but was bereft of transportation. In such a situation would not even a saint have moments of crankiness? Professor Cluse has now fully recovered and ! am happy to say his accident has triggered off a research program at our western school of forestry. A series of studies has been initiated to produce tree growth in circular shapes which could be used not only for tennis rackets but which, on a larger scale, may bring about a rebirth of the wooden bicycle rim.

Nemorensis

JACK PINE IS ...

One of the annoyances foresters have to contend with from time to time is a change in the botanical name of a common tree species. In recent years, for example, we had to learn that Douglas-fir was no longer Pseudotsuga taxifolia, but $P$. menziesii, and yellow birch no longer Betula lutea, but $B$. allegheniensis. Now we are being asked to think of jack pine as Pinus divaricata rather than the old familiar $P$. banksiana.

The cause of all this trouble is the long-term delayed application of the botanical rule that he who first satisfactorily describes a plant shall have the honour of naming it. Of course, as long as a plant's description and taxonomic position are in doubt, naturally its name must be subject to change. But here is a well-defined common tree that is the subject of a voluminous literature, and whose scientific name is known to thousands outside the botanical discipline. It now turns out that an early botanist, now deceased, described and named it Pinus divaricata before Lambert called it $P$. banksiana. By all means let us acknowledge his accomplishment and give credit where credit is due, but then let it go at that.

It is time for botanists to retire the indiscriminate application of this rule after such delays. As for changing the name of jack pine, the confusion, nuisance, and cost to foresters, scientists, and libraries everywhere are out of all proportion to the small amount of justice done to either the original namer or his discoverer.

A. H. Teich and C. E. Van Wagner Petawawa Forest Experiment Station Chalk River, Ont.

(Note. See also previous items on the subject in the Chronicle: 48, pages 71 and $173 ; 49$ pages 14.)

\section{DELAY FOLLOWS ACT}

Section 2 of the Official Languages Act provides as follows:

The English and French languages are the official languages of Canada for all purposes of the Parliament and Government of Canada, and possess and enjoy equality of status and equal rights and privileges as to their use in all the institutions of the Parliament and Government of Canada. 1968-69, c. 54, s.2.

Information Canada, in delaying the publication of The Forest Regions of Canada until the English and the French versions are ready, is clearly respecting the terms, spirit and intent of the Act. In the past there have been too many examples of government publications being released in English months, if not years, before the French version. The opposite, somehow, never seems to happen.

I am sure you agree that this is not fair and one of the purposes of the Official Languages Act is to stop that practice.

Trusting that the foregoing will be helpful, I remain

\section{Keith Spicer}

Commissioner of Official Languages Ottawa 
June 1933. My thesis is that under our physical and economic conditions land transportation is the most important factor in all principal phases of forest management, i.e., in silviculture, in protection and in logging. Our success or failure in forestry is very largely determined by this factor and by our judgment and skill in controlling it.

We depend for land transportation of wood in the course of logging most of all on manual and horse labour, to a much smaller degree on machinery, and the least of all on the force of gravity. From the point of view of economy and efficiency it would be very desirable to reverse this order. This will be done when in the bush brains will be placed on a par with muscles.

The future of our forests on areas under exploitation is being shaped now; it is shaped by our logging practices. Transportation, and particularly land transportation in the course of logging, is responsible for the character and value of future forests much more than any other controllable factor. This is one of the fundamentals of commercial forestry, even if the fact is not widely recognized.

The fact that in logging, cutting chronologically precedes transportation, causes an entirely fallacious conception that our transportation methods are determined by cutting methods. I wish to point out emphatically that actually the reverse is true: that under given economic and physical conditions our cutting practices are dependent on and are determined by subsequent transportation of timber.

There is room enough in our woods operations for such feasible improvements as do not clash with economic necessities but favour forestry without infringing on the efficiency of logging.

Right now we can make two good steps in the right direction, by recognizing that the way to introduce silviculture into the bush is through logging and particularly through land transportation; and that such efforts are particularly through land transporta- tion; and that such efforts are particularly desirable as favour both land owner and operator.

With our woods operations very distant from headquarters and scattered over wide areas of wild country, administration and supervision can be only as efficient as are the available means of transportation.

It is generally recognized that progress in our woods operations is often retarded, if not paralyzed, by the lack of correct understanding of vital problems by those who are in authority to decide. We would strive to help them to realize, among other pertinent fundamentals, that transportation is the backbone of forestry and the master key to economy and efficiency in all departments of forest management. / Koroleff.

June 1953. Forest management is the art of producing forests and forest products by applying to an area of land the principles and techniques of silviculture, engineering, science and business. A knowledge of cutting systems, airphoto interpretation, soil formation, forest succession and economic theory, in fact all knowledge, must be actually used for the production of forests on a specific area before it can be considered forestry. Forest production depends upon specific combinations of the capabilities of the land, the potentialities of the forest which grows upon that land, and the ability of the man who manages both forest and land. It is not enough to know the general effect of a certain soil feature upon forest growth, rather it is essential to know what specific effect can be expected when that soil feature is found within a specific unit of the forest environment. This means that there must be a consideration of all the interrelationships of all the features which determine production upon a given area. The forest environment is an integrated combination of soi!, climate and forest, existing either in a natural state or in a form which has been modified by man. Each unit of a manmodified environment is a specific example of the effect of social, economic and technological controls upon the adjustment which a forest community must make to local combinations of soil and climate. If the forest environment is broadly conceived as an integrated system of physiographic (i.e. soil and climate) and biotic features, in other words a system which embodies both the forest and the forester, then forest management becomes the manipulation of environment. Without an intimate knowledge of total environment we can exploit the forest, but we cannot manage it. / Hills

\section{STOP WASTEFUL USES}

Folkema's points are well taken (The use and misuse of public forests in Ontario. Forest. Chron. 49:7-9) and most of us will agree that stiffer legislation is necessary when dealing with natural resources, such as forests. However, it should be clear that legislation must be supported by an answer to the problem to make it effective. For instance, we "recommend to undertake a comprehensve project to develop adequate regeneration techniques..." (Can. Dep. Environ. Res. Newsletter 2, 1972), meaning that we have to wait for the results which will ultimately outline silvicultural management practices for the important tree species of the northern forests.

Silviculture, as we know it today, deserves a break. If it is done 'comme il faut', it includes, ecologically and economically speaking, all the good things we were talking about in the last few years. To grow bigger trees faster ceased to be the prime objective in forestry. Why not take, in a way, a negative attitude and introduce legislation to stop the wasteful use of fibre in our everyday life and industry.

\section{G. Stroempl}

Barrie, Ont.

\section{What is forestry for Participation 13}

Possibly forestry has been redefined more times than any other word. We ask you to send in either your own definition of forestry or the one (and source) that you consider is best.
Send your participation to: The Editor, The Forestry Chronicle, 17 Elizabeth St. N., Richmond Hill, Ontario, L4C 4N4. Deadine: July 31. Offerings will appear in the October issue. 


\section{ACRONYM}

\section{(Associated Committee Regulating Ontario-New York Marketing)}

Will FRIG's (Forest Resources Inventory Group) INCONGRUOUS (Integrated National Committee On New Guidelines Regulating Utilization of Uncut Stands) format lead to a PRANG (Policy Research And New Guidelines) committee or SNAFU (Society for New Approaches to Forest Utilization) for Canadian forestry? Did CUT (Committee for Utilizing Timber) produce STUMP (Silvicultural Treatment Using Mechanized Practices)? Was SAP (Silviculture Advancement Program) removed? Or was it all a FARCE (Forests After Recent Clearcut Exposure) are the questions that arise from G. Pierpoint's (King City, Ontario) list of acronyms for Participation II.

H. J. Paul (Prince Albert, Sask.) knew that the acronyms he submitted were not in actual use but if a name is available, he wrote, some government would set up the organization. He suggested 2 organizations: CHIEFS (Canadian Humanitarian Institute of Environmental Studies) and BRAVES (Believers of Reasonable Administration and Vital Environmental Studies). A campaign should be mounted to increase membership in the latter organization as there have always been too many in the former.

He also suggested that the CIF be changed to the Forester And Resource Technician Society. (Perhaps Professor R. M. P. D'Orset was in fact a member of this Society rather than of the Titubants see p. 60 of the April issue. And did you see anything in the good Professor's portrait? If not, look again.)

G. Croome (Fredericton, N.B.) came up with a selection which was related to the time of the year and state of health of his family. His suggestions were COF and COLD (Canadian Organization of Foresters, and Committee On Land Development), LARINGITES (Local and Regional Institutes for National and General Investigations in the Technical and Environmental Sciences) and the committee on FLU (Forest Land Usage).

D. Ormerod (Swaziland) thought of CRAP (Canadian Resources Action Plan).

Both Warren Robertson (Toranto, Ont.) and F. J. Hutcheson (Fredericton, N.B.) sent in longer pieces with somewhat similar endings. Robertson visualized a plague of dissidents that soon influenced politicians making important resource decisions:

A shocked forestry profession began to take action and formed groups to tell the true story of resource manage- ment. First on the scene was SLASH (Sensible Logging Always Seems Horrible) closely followed by $\mathrm{CHOP}$ (Clearcuts Heal Over Pleasantly). A forest industries association organized a mailing program called RIDIC (Realistic Information for Dreamers In Canoes).

However, they suspected their efforts were in vain when thousands of jobless college graduates with an OFY (Overpowering Forestry Yahoos) grant demanded a gigantic outdoor commune. When the spokesman for SCRWD (Student Conjugation on Rivers and Woodlands Daily) convinced the government to set aside one half of Northern Ontario for this exclusive use, foresters finally admitted they were.

Hutcheson sent in this excerpt from an undiscovered history of the Canadian institute of ofrestry:

There was in those days a plague of preservationists upon the land, who did make much noise and smoke, not literally as much as the slash burnings, but enough to irritate and annoy all citizens, whether informed or not. Because of the pressure of these people, two groups did form in the Forestry profession; the first group did say that the preservationists had much to recommend. their thought, and did call themselves by the name FIBRE which meaneth 'Foresters Interested in Bettering Resource Ecology'. The other group did call themselves FOREST, meaning 'Foresters Operating for Reasonable Exploitation of Standing Timber'. These two groups did spend many CIF meetings arguing about their points of view, until it became necessary, so that the Institute would'st not flounder upon the rocks, to send a call throughout the land that there would be a conference, to be called NUMBER (New Universal Mensuration of Biological and Environmental Resources). This conference was called so that all Foresters would agree on, at least, basic definitions.

This conference did agree that there were several questions which should be answered. To this end they did set up a group which was called CRUISE (Canadian Resources: Utilization, Inventory, Study and Evaluation). Having a new view of the problem of Forestry in Canada, there must needs be as well a meeting named CRUD (Conference on the Resources of Universities and their Development). This gathering did suggest the formation of five SPRUCE's (Special Purpose Regional University Committee on the Environment). At the same time, all Foresters, as a result of the NUMBER were charged to go out and preach the good word to all people, especially those in PINE (People Intent on Nature and Ecology) that they may be converted unto the truth.

And when all had been accomplished, and all information was in readiness, the final and ultimate gathering was convened and was named COPOUT (Confrontation to Optimize Policies for Overall Utilization for Tomorrow). The gathered people at this meeting did agree on a plan which would govern all resource use and did christen it PLUNDER (People Linked Utilization with Natural Development of Environment Resources). This plan did hold sway for many years, until GULP (General Universal Learning Program) did appear, at which time, since everybody did know as much as the next, all divisions based on education did disappear, and foresters were no more.

Even though foresters have disappeared from the earth as a professional group, we still retain one major gift they have bequeathed to the following centuries, the Forestry Undergraduate Committee for Knowledge. 
Pith to Periderm describes the Koehring short-wood harvester in action in the highlands of Cape Breton on the limits of Nova Scotia Forest Industries as follows.

It is a huge machine 33 feet long, 15 feet wide, 19 feet high, weighs 90,000 pounds unloaded, has tires approximately 3 feet wide and 9 feet high, and a load capacity of 5.9 cunits ( 7 cords). Controlled by one operator it moves slowly over the ground and most obstacles, grabs whole trees, shears them off near the base, then swings them around to the process tower for limbing and shearing into 8-foot bolts that are stored in the cradle. One observer was moved to remark, "Yes, but is it bilingual?"

According to an item in The Logger Letter stems of street trees in Tokyo are wrapped in layers of rice straw in the fall. Bugs reputed!y crawl into the straw to stay warm and lay eggs. In the spring the straw is removed and burned.

No bugs. But all that smoke?

This is the year of Ecology. Litterbugs who did not even know what the word meant six months ago are climbing on the bandwagon . . . Once a college wasn't big-time unless it had a 50,000seat stadium. Later, prestige required a cyclotron, more recently a hyperbaric chamber. Now academic status is a Department of Environmental Science.

The date? 1970. The source? An editorial in Popular Mechanics.

The abstract of a paper given at the 28th meeting of the Eastern Snow Conference stated "some work is being undertaken to develop the potential of snow in education".

We thought it was already developed by certain educators.
Fractured dendrology, contributed by J. C. Lees ( $U$ of A, Edmonton):

\begin{tabular}{|c|c|}
\hline Serrate & $\begin{array}{l}\text { What will be, } \\
\text { will be }\end{array}$ \\
\hline Undulate & $\begin{array}{l}\text { Forest and range } \\
\text { animal }\end{array}$ \\
\hline Acicular & Sawmill \\
\hline Pubescent & Fourteen \\
\hline Sessile & Sitting down \\
\hline Serotinous & $\begin{array}{l}\text { Johnny-come- } \\
\text { lately }\end{array}$ \\
\hline Hybrid & $\begin{array}{l}\text { Tall pregnant } \\
\text { woman }\end{array}$ \\
\hline Glaucous & Loud and happy \\
\hline Orbicular & Big breasted \\
\hline Striate & Mother-in-law \\
\hline
\end{tabular}

The forest scientist lives in a world all to himself, concentrating, studying and diligently working in an ever narrowing field until he is an accepted expert knowing everything there is to know about nothing.

The forest manager is given a broad background on a wide variety of subjects. As he develops in his profession he spreads his talents in ever expanding spheres until he knows nothing about everything.

The forest technician starts off with a reasonable understanding of all fields of forestry and, left to his own devices, could carry out assignments in any of these fields quite competently. However, after severe exposure to forest scientists and forest managers he evolves to the stage of knowing nothing about everything.

Adapted by D. A. Skeates (Willowdale, Ont.) from Murphy's Law of Engineering.

"Mr. G, although, trained in forestry, has always been engaged in the logging end of the forestry industry." / The Globe and Mail.

And never the twain shall meet?
Two advertisements in the August 1972 issue of the Journal of Forestry caught our eye. One started Multiple Use Forester seeks responsible forest management position; the other listed the advertiser as being $e x$ perienced in fire control, landscaping, seeding and guard rail construction.

According to Herbert Whittaker in The Globe and Mail, the mod. ern Soviet poet Yevgeny Yevtushenko has coined a new word, forestration, to describe the Cana. dian condition. Whittaker adds, however, that Canadians should hear how he pronounces his new word. "He slurs the first half, and grins wickedly as he brings it that much closer to frustration."

Dirt forestry. Remember that tree, pulp, wood, leaf, root, site, bole, twig and cone are four-letter words.

Our suspicions were confirmed when looking at a table in Special Study No. 26 Governments and Innovation, A Background Study for the Science Council of Canada. The Table lists the professional backgrounds of members of the House of Commons: law, agriculture, education and so on. But the last in the list is perhaps the most interesting - Not Known and Vacant.

The Georgian College Summer School of Arts, Ontario, is offering a 2-day course "to explore the mysteries of the forest". The description of the course continues: "We'll discover by doing, so be prepared to get your feet wet and your hands dirty, to be eaten by mosquitos and yet to gain new incite and inspiration from your days in the forest."

No doubt we'll learn how to make placards from birch bark. 


\section{Oh where, oh where has my Chronicle been?}

Dear Sir:

In response to your survey of

Canadian postal efficiency, the latest issue of the Forestry Chronicle arrived on February 23rd, being 15 days after mailing from its point of origin. Assuming said point of origin to be Montreal, I think it is indicative of the underlying strength of this country that we still have letter carriers who are prepared to walk 40 miles a day. Presumably this dedicated chap will be back to Montreal in time to pick up the April issue of the Chronicle.

Yours truly,

J. Russell Powell

Simcoe, Ont.

We received 55 replies to our request on the cover of the February issue in an attempt to track down how long it takes readers to receive The Forestry Chronicle. Within Canada, we are afraid that the Post Office's row boat must have sprung a leak because no replies were received from Newfoundland or Prince Edward Island. Nor did we receive any word from Manitoba. (Maybe they tried rowing there instead.) We only hope that the other 2,500 or so copies sent to destinations in Canada and elsewhere in the world arrived safely.

You can see how you fared in relation to others by looking at the time it took the issue to reach various places. A number of people remarked on the speed with which they received their copy and congratulated us on having found a way to hasten delivery. Last year, the average time for delivery of the 6 issues was 10 days - varying from 8 to 17 days - from Montreal to Richmond Hill.

Why Musquodoboit Harbour and the hamlet of Petersham, Mass. should be so honoured is perhaps only known to the Post Office though we doubt even that. Such 4-day delivery for 3rd class mail is hard to fathom out when Art van Slyke at Petersham received his December issue only 2 days before his February one (December 13 to February 10), and the editor's copy, sent first class, also took 4 days to reach Richmond Hill, Ont.

The spread in time for delivery to a specific place seems to depend on what letter of the alphabet your name starts with - the bottom of the pile at the time of mailing is still the bottom out at Victoria. For example, Arnott in Victoria received his on day 20 and Todd on day 25; in Edmonton Beck received his on day 7, Schultz on day 8 and Waldron not until day 12.

Mail is slow in Oregon. L. P. Larsen felt delivery of his issue in 29 days wasn't bad considering it could take a week for a first class letter to go 30 miles between towns. If you live in Oregon and want faster delivery of the Chronicle, you would be better off to move to England. Would you want to swop Hawaii for Swaziland? Maybe that row boat bound for Newfoundland went off course and landed in Puerto Rico instead!

Is your address on mail received from the CIF correct?

Is your name spelt properly?

Is the street address complete?

- Is the correct (latest) name of your organization listed?

- Has your Postal Code been used?

If there is anything wrong or missing, send your correct address NOW to the Canadian Institute of Forestry, Box 5000, Macdonald College, Quebec. Who knows, you might have the pleasure of being the first one to receive the next edition of the Chronicle.

Day

O Mailed 3rd class from Gardenvale, (Montreal) Que.

1

3 SUNDAY

4 Musquodoboit Harbour, N.S./ Petersham, Mass.

5 Pointe Claire, Que.

6 Hamden, Conn.

7 Truro, N.S. / Nashwaaksis, N.B. / Ottawa, King City and New Liskeard, Ont. / Prince Albert, Sask. / Edmonton, Alta.

8 King City, Strathroy and Sault Ste. Marie, Ont. / Edmonton, Alta.

9 Happy Valley, Labrador

10 SUNDAY

11 Fredericton, N.B. / Toronto, Chalk River, North Bay, Thunder Bay and Sioux Lookout, Ont. / Penticton and Vancouver, B.C.

12 Fredericton, N.B. / Barrie and Fort Frances, Ont. / Edmonton, Alta. Surrey and Vancouver, B.C.

13 Sheridan Park and Peterborough, Ont.

14 Kanata and Stittsville, Ont.

15 Simcoe, Ont.

16 Kensington, Maryland.

17 SUNDAY

18 Seattle, Wash.

19

20 Victoria, B.C.

21 Farnham, England

22

23

24 SUNDAY

25 Victoria, B.C.

26 Oakridge, Ore.

27

28 Eugene and Portland, Ore.

29 Medford, Ore.

30

31 SUNDAY

32

33

34

35

36 Mhlambanyati, Swaziland

37

38 SUNDAY

39

40

41

42

43 Honolulu, Hawaii

44

45

$\bullet$

-

70 Rio Piedras, Puerto Rico 